\title{
STUDIES ON SULFHEMOGLOBIN FORMATION BY VARIOUS DRUGS (5) THE MECHANISM OF SULFHEMOGLOBIN FORMATION AND SPECIES DIFFERENCES IN METHEMOGLOBIN AND SULFHEMOGLOBIN FORMATION
}

\author{
Akira NOMURA and Hajime FUJIMURA \\ Department of Pharmacology, Gifu University School of Medicine, Gifu 500. Japan
}

Accepted March 15, 1981

\begin{abstract}
The mechanism of sulfhemoglobin ( $\mathrm{SHb}$ ) formation and species differences in the formation of $\mathrm{SHb}$ and methemoglobin (MHb) were investigated. Erythrocytes or hemolysates were incubated with phenylhydroxylamine (PHA), aniline or its monochloro derivatives in the presence or absence of liver microsomes from various species (mouse, rat, guinea pig, rabbit, cat, dog and monkey). It was confirmed that $\mathrm{SHb}$ was produced by the $\mathrm{N}$-hydroxy metabolites of aniline and its derivatives and was not induced via $\mathrm{MHb}$. There was a relationship in $\mathrm{SHb}$ or $\mathrm{MHb}$ formation between the chemical structure of aniline derivatives and their $\mathrm{N}$-hydroxy metabolite production activities in the animals (in vivo and in vitro). Species differences in the production rates of $\mathrm{N}$-hydroxy metabolites from aniline and its derivatives by liver microsomes (as well as in the susceptibility of erythrocytes to $\mathrm{N}$-hydroxy compounds) in vitro were not reflected in species differences in $\mathrm{MHb}$ and $\mathrm{SHb}$ formation in vivo.
\end{abstract}

The observation that a $\mathrm{N}$-(4-chlorophenyl) ethylurethane derivative caused typical sulfhemoglobinemia in animals led us to study the forming activities of methemoglobin $(\mathrm{MHb})$ and sulfhemoglobin $(\mathrm{SHb})$ by various compounds such as aniline, $N$-phenylanthranilic acid and $\mathrm{N}$-(1-naphthyl) anthranilic acid derivatives, and reported the relationship between their $\mathrm{MHb}$ or $\mathrm{SHb}$ forming activity and chemical structures (1-3). In those studies, it was suggested that not only $\mathrm{MHb}$ but also $\mathrm{SHb}$ was produced by $\mathrm{N}$-hydroxy metabolites of the aniline derivatives described above. Further it was suggested that SHb might be produced via $\mathrm{MHb}$ because SHb formation was remarkably later than that of $\mathrm{MHb}$. On the other hand, there is considerable evidence that $\mathrm{SHb}$ formation is not via MHb, for example. only $\mathrm{SHb}$ was produced by phenylurethane derivative (1) and the SHb formation was prevented by the pretreatment with ascorbic acid, which did not inhibit $\mathrm{MHb}$ formation (4).

The present study was designed to clarify $\mathrm{MHb}$ and $\mathrm{SHb}$ formation using mainly aniline and phenylhydroxylamine. We also investigated species differences in the formation of $\mathrm{SHb}$ and $\mathrm{MHb}$.

\section{MATERIALS AND METHODS}

Animals used were as following: male ddY-Slc mice $(25-34 \mathrm{~g})$, male SD-Slc rats 
(120-280 g) and male Hartley-STD guinea pigs (350-650 g) [Shizuoka Agric. Co-op. Assoc. for Laboratory Animals]: male JWNIBS/RABITON rabbits $(2.1-2.8 \mathrm{~kg})$ [RABITON Farm. Inc.]; male and female cats $(1.6-3.7 \mathrm{~kg})$ [Nakajima Laboratory Animals Co.]; male beagle dogs $(9-14 \mathrm{~kg})$ [Laboratory Research Enterprises, Inc.] and male rhesus monkeys $(5.3-6.1 \mathrm{~kg})$ [Research Primates Japan Co.].

The chemicals used were as following: aniline hydrochloride (aniline), magnesium chloride, nicotinamide, phenylhydroxylamine (PHA), potassium ferricyanide, powder of sulfur and sodium sulfide [Wako Pure Chemical Industries]; 2-chloroaniline hydrochloride (2-Cl-A), 3-chloroaniline hydrochloride $(3-\mathrm{Cl}-\mathrm{A})$ and 4 -chloroaniline hydrochloride (4-Cl-A) [Tokyo Chemical Industry Co.]; bovine serum albumin (Fraction $V$ ). glucose-6-phosphate disodium salt and glucose-6-phosphate dehydrogenase [Sigma Chemical Co.] and nicotinamide-adenine dinucleotide phosphate sodium salt (NADP) [Oriental Yeast Co.].

The amounts of $\mathrm{MHb}$ and $\mathrm{SHb}$ were measured by the modified method (1) of Evelyn and Malloy (5).

1) Experiments in $\mathrm{MHb}$ and $\mathrm{SHb}$ formation with intact erythrocytes and hemolysates in vitro

Fresh blood was drawn from healthy human beings and animals of various species described above. Erythrocytes were spun down and the plasma was discarded. Erythrocytes or hemolysates were incubated in M/15 phosphate buffer solution ( $\mathrm{pH} \mathrm{7.3-7.4)}$ at $37^{\circ} \mathrm{C}$ for 30 minutes. Hemolysate solution was obtained by hemolysis of erythrocytes which was produced by adding hypotonic phosphate buffer solution ( $\mathrm{M} / 60)$ ), and then the final concentration of phosphates was adjusted to $M / 15$ (isotonic). The final concentration of hemoglobin was adjusted to $10 \mathrm{~g} / \mathrm{dl}$ both in erythrocyte suspension and hemolysate solution.

a) $\mathrm{MHb}$ and $\mathrm{SHb}$ induced by $\mathrm{PHA}$ : In the experiments in $\mathrm{MHb}$ formation, erythrocyte suspension or hemolysate solution prepared from the blood of guinea pigs was incubated with various concentrations of PHA. For the experiments in SHb formation, erythrocyte suspension or hemolysate solution was incubated with various concentrations of PHA in the presence of sodium sulfide. An aliquot of each reaction mixture was taken for the measurement of $\mathrm{MHb}$ and $\mathrm{SHb}$.

b) Incubation of $\mathrm{MHb}$ with PHA and sodium sulfide: $\mathrm{MHb}$ was prepared by treatment of the hemoglobin from guinea pigs with potassium ferricyanide. It was incubated with PHA $(0.05 \mathrm{mM})$ in the presence of sodium sulfide $(0.2 \mathrm{mM})$. The sample was taken from the incubation mixture for the measurement of absorption spectra.

c) $\mathrm{MHb}$ and $\mathrm{SHb}$ formation by $\mathrm{PHA}$ or aniline with hemoglobin of various animal species: Erythrocytes and hemolysates were prepared from fresh blood of various animal species by the methods described above and were incubated with PHA or aniline at a final concentration of $0.05 \mathrm{mM}$ in the absence or presence of sodium sulfide $(0.2 \mathrm{mM})$.

d) Hepatic microsomal $\mathrm{N}$-oxidations of aniline, 2- $\mathrm{Cl}-\mathrm{A}, 3-\mathrm{Cl}-\mathrm{A}$ and 4- $\mathrm{Cl}-\mathrm{A}$ : Hepatic microsomal fractions from animals of various species were prepared by the method of Hogeboom (6). The content of microsomal protein was determined by the method of Gornall et al. (7), using bovine serum albumin as a standard.

According to the method of Hjelm and Verdier (8), in each case, $10 \mu$ moles of aniline, 2-Cl-A, 3-Cl-A and 4-Cl-A were incubated with $5 \mathrm{ml}$ of solution containing magnesium chloride (5.71 $\mathrm{mg}$ ), nicotinamide (14.65 mg), NADP (2.01 mg), glucose-6phosphate (16.32 mg), glucose-6-phosphate dehydrogenase (1.4 unit) and liver microsomes (0.125-0.5 mg of microsomal protein) 
at $37^{\circ} \mathrm{C}$ for 60 minutes.

To each reaction mixture was added $5 \mathrm{ml}$ of erythrocyte suspension from guinea pigs for another 30 minute incubation in the absence or presence of sodium sulfide $(0.2$ $\mathrm{mM}$ ). The final concentration of hemoglobin in erythrocyte suspension was adjusted to $10 \mathrm{~g} / \mathrm{dl}$. A sample of each reaction mixture was taken for the determination of $\mathrm{MHb}$ and $\mathrm{SHb}$.

2) Experiments in $\mathrm{MHb}$ and $\mathrm{SHb}$ formation and species differences therein in vivo

In order to determine $\mathrm{MHb}$ formation and species differences of $\mathrm{MHb}$ formation, animals of various species were given $\mathrm{PHA}$, aniline. 2-Cl-A, 3-Cl-A and 4-Cl-A intraperitoneally. Blood was drawn at various intervals for the determination of $\mathrm{MHb}$. In the case of $\mathrm{SHb}$ formation, animals were given $\mathrm{PHA}$, aniline and $4-\mathrm{Cl}-\mathrm{A}$ intraperitoneally with powder of sulfur (750 mg/kg/day p.o.) for three consecutive days. The SHb levels were measured 48 hours after the final administration.

\section{RESULTS}

1. Experiments in $\mathrm{MHb}$ and $\mathrm{SHb}$ formation with intact erythrocytes and hemolysates in vitro

1) $-1 \mathrm{MHb}$ formation by PHA: The results are shown in Fig. 1. The formation of $\mathrm{MHb}$ increased, depending roughly on the final concentration of $\mathrm{PHA}$ in the range from 0.003 to $0.1 \mathrm{mM}$ in erythrocyte suspension or hemolysate solution of guinea pigs. $\mathrm{MHb}$ formation reached a plateau over $0.1 \mathrm{mM}$ PHA concentration. At the hemoglobin concentration used in this experiment, the maximum concentration of PHA was obtained as $0.1 \mathrm{mM}$ for erythrocytes and hemolysates. $\mathrm{MHb}$ formation in erythrocyte suspension by $\mathrm{PHA}$, at each concentration, was more potent than that in hemolysates, while $\mathrm{SHb}$ formation was not observed at all in the case of either erythrocytes or hemolysates.

1) -2 SHb formation by PHA: The results are shown in Fig. 2. When erythrocytes or hemolysates from guinea pigs were incubated

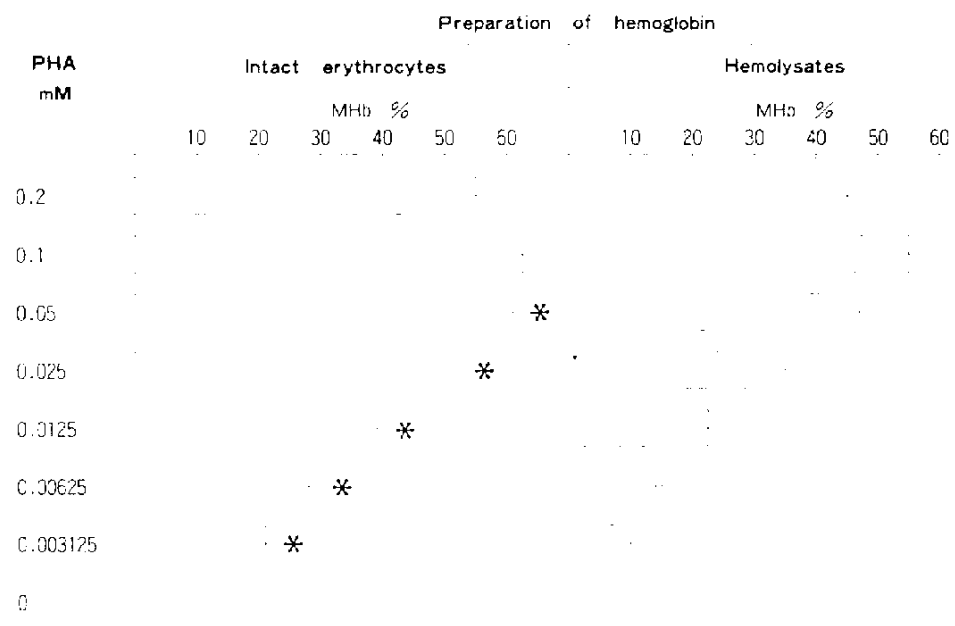

Fig. 1. Methemoglobin formation of guinea pig hemoglobin incubated with various concentrations of phenylhydroxylamine (PHA). Erythrocytes or hemolvsates were incubated at $37^{\circ} \mathrm{C}$ for $30 \mathrm{~min}$. The final concentration of hemoglobin was adjusted to $10 \mathrm{~g} / \mathrm{dl}$. Each value indicates the mean \pm standard error of 3 experiments. *: Significantly different from levels obtained with hemolysate solution, $p<0.01$ (Student's $t$-test). 


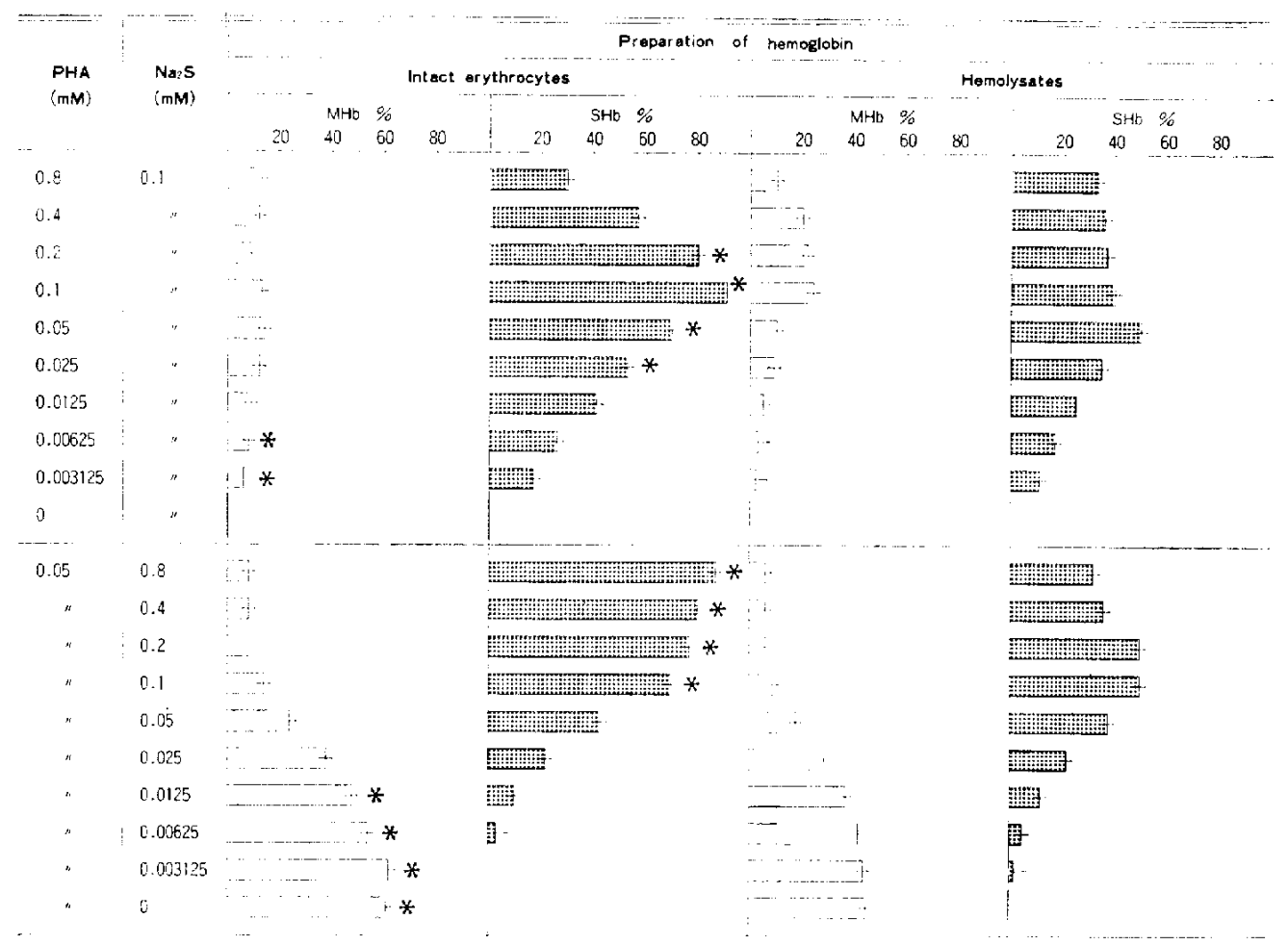

Fig. 2. Methemoglobin and sulfhemoglobin formation of guinea pig hemoglobin incubated with various concentrations of phenylhydroxylamine (PHA) and sodium sulfide $\left(\mathrm{Na}_{2} \mathrm{~S}\right)$. Erythrocytes or hemolysates were incubated at $37^{\circ} \mathrm{C}$ for $30 \mathrm{~min}$. The final concentration of hemoglobin was adjusted to $10 \mathrm{~g} / \mathrm{dl}$. Each value indicates the mean \pm standard error of 3 experiments. *: Significantly different from levels obtained with hemolysate solution, $\mathrm{P}<0.01$ (Student's t-test).

with PHA in the presence of $0.1 \mathrm{mM}$ sodium sulfide, $\mathrm{SHb}$ was induced in a dose dependent manner, increasing up to $0.1 \mathrm{mM}$ and 0.05 mM PHA concentration for erythrocytes and hemolysates respectively. In erythrocytes, a sharp concentration-dependent decrease of $\mathrm{SHb}$ formation was observed at concentrations of over $0.2 \mathrm{mM}$ PHA. In hemolysates, on the other hand, SHb formation at concentrations of over $0.1 \mathrm{mM}$ was slightly decreased. A remarkable SHb formation was observed in erythrocytes compared to that in hemolysates.

When $0.05 \mathrm{mM}$ PHA was added to the erythrocyte suspension under various concentrations of sodium sulfide, SHb formation was increased, depending on the amounts of sodium sulfide. In other words, when less sodium sulfide was added, more $\mathrm{MHb}$ was produced and when large amounts of sodium sulfide were added, more $\mathrm{SH}$ b was produced. In the case of hemolysates, the increase of $\mathrm{SHb}$ was dependent on the sodium sulfide concentration up to $0.1 \mathrm{mM}$ and $\mathrm{SHb}$ was decreased at over $0.2 \mathrm{mM}$ sodium sulfide. Also, $\mathrm{SHb}$ formation was greater in erythtrocytes than in hemolysates. In a separate experiment, unexpectedly, the amounts of $\mathrm{MHb}$ which had already been formed by PHA in the absence of sodium sulfide were not affected by post-treatment of sodium sulfide. namely, SHb was not produced unless the coexistence of PHA and sodium sulfide.

2) The incubation of $\mathrm{MHb}$ with PHA and 


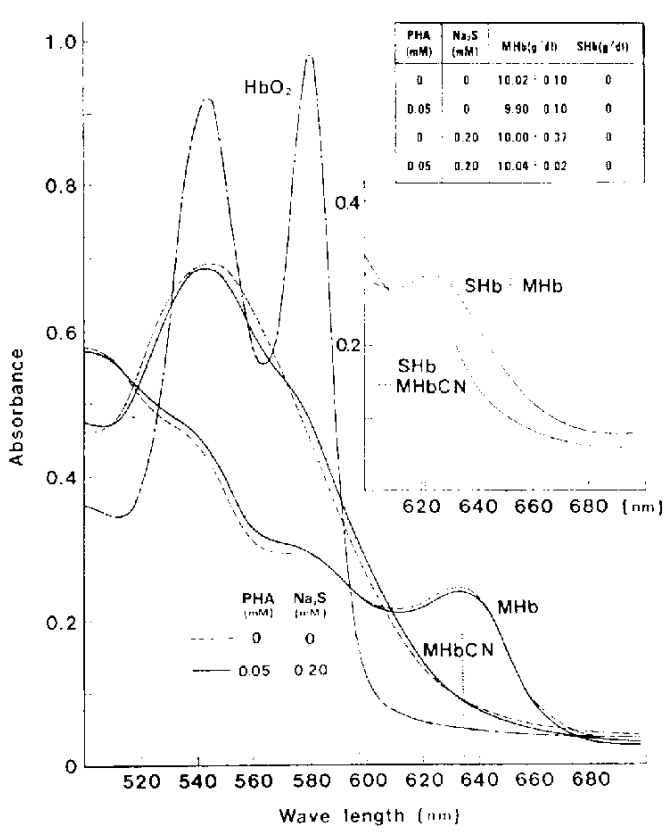

Fig. 3. Effects of phenylhydroxylamine (PHA) in the presence of sodium sulfide $\left(\mathrm{Na}_{2} \mathrm{~S}\right)$ on methemoglobin prepared from hemoglobin of guinea pigs. The absorption spectra of methemoglobin incubated with PHA in the presence of $\mathrm{Na}_{2} \mathrm{~S}$. Figure insert - the absorption spectra of the mixture of sulfhemoglobin with methemoglobin or cyanmethemoglobin. Table insert-the incubation of methemoglobin with PHA in the presence of $\mathrm{Na}_{2} \mathrm{~S}$ did not lead to the sulfhemoglobin formation.

sodium sulfide: When sodium cyanide was added to a mixture of $\mathrm{MHb}$ and $\mathrm{SHb}, \mathrm{SHb}$ remained unchanged with the characteristic absorption peak of $622 \mathrm{~nm}$, as shown in the inset figure of Fig. 3, while the $\mathrm{MHb}$ absorption at $635 \mathrm{~nm}$ was eliminated due to the conversion of $\mathrm{MHb}$ to cyanmethemoglobin (Fig. 3). When MHb prepared from guinea pig hemoglobin was incubated with $0.05 \mathrm{mM}$ PHA in the presence of $0.2 \mathrm{mM}$ sodium sulfide, no $\mathrm{SHb}$ formation occurred from $\mathrm{MHb}$, as shown in Fig. 3 (inset).

3) $\mathrm{MHb}$ and $\mathrm{SHb}$ formation by $\mathrm{PHA}$ or aniline with hemoglobin of various animal species: Erythrocyte suspension and hemolysate solution were prepared from fresh blood of mice, rats, guinea pigs, rabbits, cats, dogs, monkeys and human beings, by the method described above. Each was incubated with $0.05 \mathrm{mM}$ PHA or aniline in the absence or presence of sodium sulfide $(0.2 \mathrm{mM})$. The results are shown in Fig. 4. Aniline, unlike PHA, showed no definite forming activity with regard to $\mathrm{MHb}$ and $\mathrm{SHb}$ in any animal species. PHA was more potent in the formation of $\mathrm{MHb}$ and $\mathrm{SHb}$ in erythrocytes than in hemolysates in all animal species, and the tendency was more remarkable in $\mathrm{SHb}$ formation compared with $\mathrm{MHb}$ formation.

In the cases of erythrocytes of dogs and cats, the level of $\mathrm{MHb}$ was slightly higher, and the level of SHb was lower, than that in other species.

4) $\mathrm{N}$-Oxidation of aniline, 2- $\mathrm{Cl}-\mathrm{A}, 3-\mathrm{Cl}-\mathrm{A}$ and $4-\mathrm{Cl}-\mathrm{A}$ by liver microsomes from various animal species: As mentioned above, PHA caused formation of both $\mathrm{MHb}$ and $\mathrm{SHb}$. while aniline did not. thereby suggesting that $\mathrm{SHb}$ as well as $\mathrm{MHb}$ was produced through $\mathrm{N}$-hydroxy metabolites of aniline, namely PHA. Accordingly, the levels of $\mathrm{MHb}$ and $\mathrm{SHb}$ were measured as an index of the production of $\mathrm{N}$-hydroxy metabolites in a reaction mixture of aniline and its derivatives with liver microsomes. The results are shown in Figs. 5 and 6 . The production of $\mathrm{N}$ hydroxy metabolites from aniline was much lower in cats and monkeys and was markedly higher in guinea pigs. The same rank order was also observed in the production rate of $\mathrm{N}$-hydroxy metabolites in the various species of animals, in the case of $4-\mathrm{Cl}-\mathrm{A}$.

Making a comparison among aniline, $2-\mathrm{Cl}$ $\mathrm{A}, 3-\mathrm{Cl}-\mathrm{A}$ and $4-\mathrm{Cl}-\mathrm{A}$ in the case of mouse microsomes, the production rate of $\mathrm{N}$-hydroxy metabolites of $4-\mathrm{Cl}-\mathrm{A}$ was highest, and was followed by $3-\mathrm{Cl}-\mathrm{A}, 2-\mathrm{Cl}-\mathrm{A}$ and aniline. In the case of cat microsomes, the rank order or production rate of $\mathrm{N}$-hydroxy metabolites 


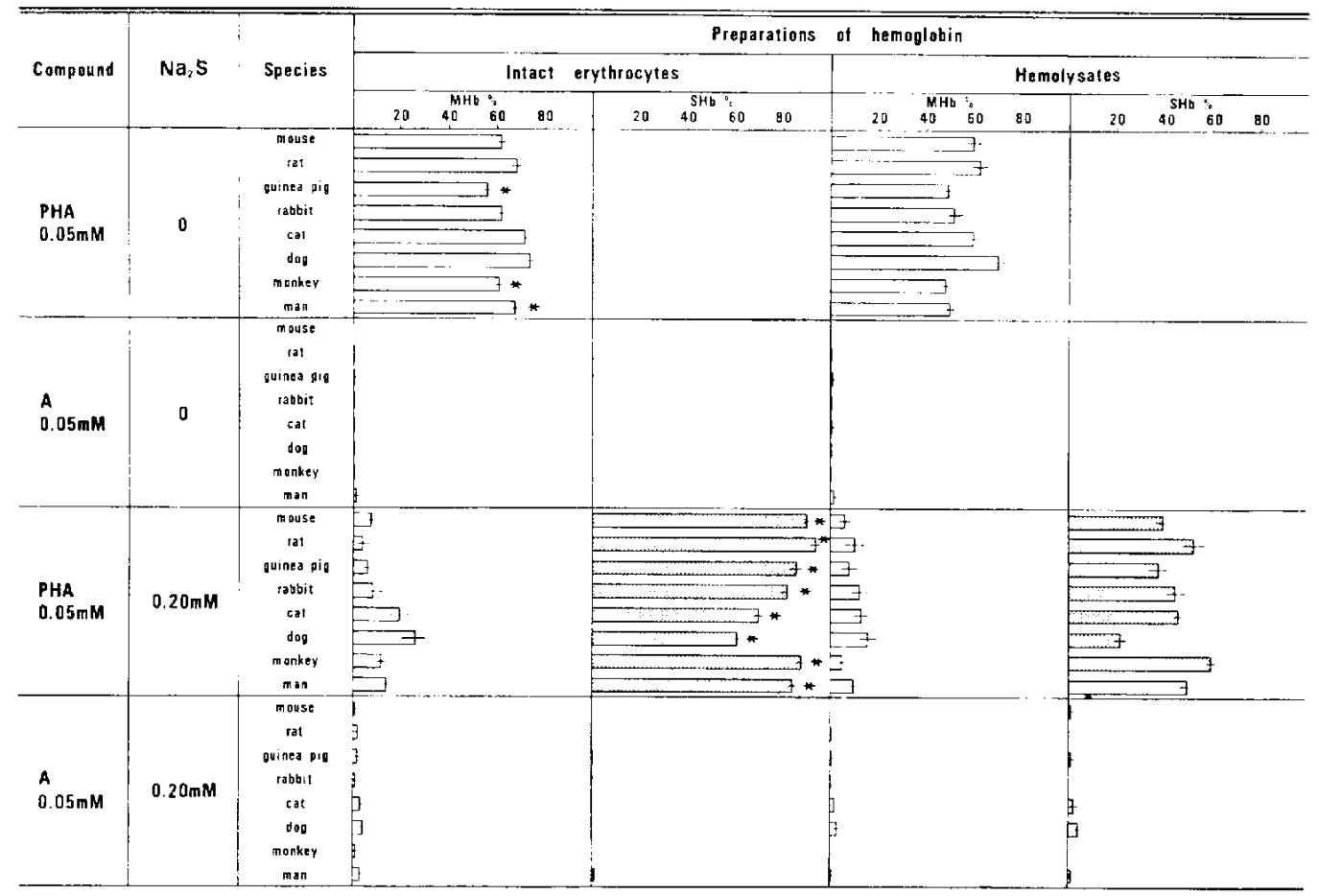

Fig. 4. Species differences of methemoglobin and sulfhemoglobin formation induced by phenylhydroxylamine (PHA) or aniline (A) in the presence and absence of sodium sulfide $\left(\mathrm{Na}_{2} \mathrm{~S}\right.$ ). Erythrocytes or hemolysates were incubated at $37^{\circ} \mathrm{C}$ for $30 \mathrm{~min}$. The final concentration of hemoglobin. PHA and $\mathrm{Na}_{2} \mathrm{~S}$ was adjusted to $10 \mathrm{~g} / \mathrm{dl}, 0.05 \mathrm{mM}$ and $0.2 \mathrm{mM}$, respectively. Each value indicates the meantstandard error of 3 experiments.

*: Significantly different from levels obtained with hemolysate solution, $p<0.01$ (Student's t-test).

was $4-\mathrm{Cl}-\mathrm{A}>2-\mathrm{Cl}-\mathrm{A}>3-\mathrm{Cl}-\mathrm{A}>$ aniline.

\section{Experiments on $\mathrm{MHb}$ and $\mathrm{SHb}$ formation} and species differences therein in vivo

The results are shown in Figs. 7 and 8 . After intraperitoneal administration of PHA, aniline and $4-\mathrm{Cl}-\mathrm{A}$ to mice, rats, guinea pigs, rabbits, cats and dogs, MHb formation was measured at various intervals. MHb formation by $\mathrm{PHA}$, aniline and $4-\mathrm{Cl}-\mathrm{A}$ in guinea pigs was less prominent than in cats and dogs. The rank order of $\mathrm{MHb}$ formation activity of animals was completely reversed to that of in vitro experiments. For $\mathrm{SHb}$ formation, the three compounds showed no activity in guinea pigs, some activity in rabbits and a somewhat higher in cats. These results also differed to the results in vitro.
To elucidate the correlation between $\mathrm{MHb}$ formation and the chemical structure, $\mathrm{MHb}$ forming activities of aniline and its monochloro derivatives were investigated in mice and cats, in vivo. The rank order of $\mathrm{MHb}$ forming activity was $4-\mathrm{Cl}-\mathrm{A}>3-\mathrm{ClA}>2-\mathrm{Cl}$ $\mathrm{A}>$ aniline in mice and $4-\mathrm{Cl}-\mathrm{A}>2-\mathrm{Cl}-\mathrm{A}>3-$ $\mathrm{Cl}-\mathrm{A}>$ aniline in cats, such corresponding to the results in vitro.

\section{DISCUSSION}

1) Mechanism of $\mathrm{SHb}$ formation: $\mathrm{MHb}$ formation by aromatic amines, aliphatic amines and nitrites is induced by their $\mathrm{N}$ hydroxy metabolites (9-13). Usually, $N$ hydroxylation of those compounds in the body is less than the C-hydroxylation, with 

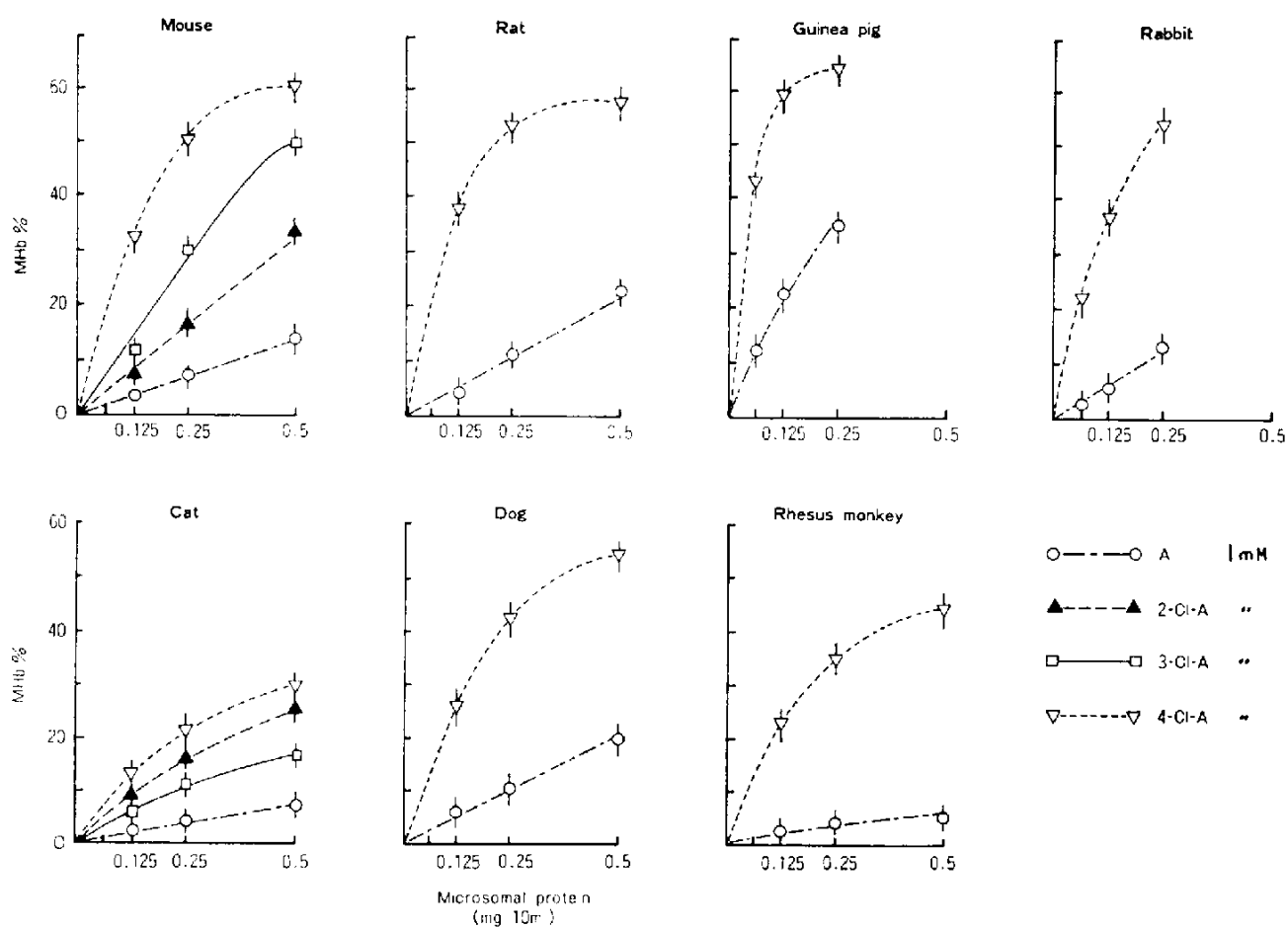

Fig. 5. Species differences of methemoglobin formation by $N$-hydroxy metabolites of aniline derivatives in erythrocytes of guinea pigs. The substrates [aniline (A). 2chloroaniline $(2-\mathrm{Cl}-\mathrm{A}), 3$-chloroaniline $(3-\mathrm{Cl}-\mathrm{A})$ and 4 -chloroaniline $(4-\mathrm{Cl}-\mathrm{A})]$ and the liver microsomes from animals of various species were incubated at $37^{\circ} \mathrm{C}$ for $60 \mathrm{~min}$. and then, the incubated mixture was added to eryrhrocyte suspension and the preparation was iricubated for a futher $30 \mathrm{~min}$. The final concentration of hemoglobin in the erythrocyte suspension was adjusted to $10 \mathrm{~g} / \mathrm{dl}$. Each value indicates the mean \pm standard error of 3 experiments.

phenacetin the $\mathrm{N}$-hydroxy metabolites were detected at a rate of less than $0.52 \%$ of the administered dose (14). However $N$-hydroxy metabolites have toxicologically an important role in $\mathrm{MHb}$ formation and in carcinogenicity (11. 15-17).

It was reported that the ferro-hydrogen peroxide complex $\left(\mathrm{HbFe}^{\| \cdot \cdot} \mathrm{H}_{2} \mathrm{O}_{2}\right)$ was produced from oxyhemoglobin by $\mathrm{PHA}$ and it was changed to ferri-hemoglobin (HbFell, $\mathrm{MHb}$ ), with hydrogen peroxide decomposition (18). Nicholls (19) and Allen and Jandl (20) proposed that SHb was produced through the reaction of $\mathrm{MHb}$ formation. Nichol and coworkers (18) suggested that ferro-SHb (SHbFell) was produced directly from the complex $\left(\mathrm{HbFe}\right.$ ll. $\left.\mathrm{H}_{2} \mathrm{O}_{2}\right)$ in the presence of hydrosulfide. We have already reported that there was no correlation between $\mathrm{MHb}$ and $\mathrm{SHb}$ formation in a treatment with nitrite, "inorganic" hydroxylamine and a phenylurethane derivative and also that the delayed SHb formation was prevented by ascorbic acid which did not inhibit $\mathrm{MHb}$ formation (1,4). Such evidence can hardly be explained by only the one mechanism proposed by Nicholls (19) and Allen and Jandl (20). Our results showed that $\mathrm{MHb}$ was produced only by treatment with PHA or ferricyanide, in the absence of sodium sulfide, and that $\mathrm{MHb}$ was never converted to SHb when sodium sulfide was 

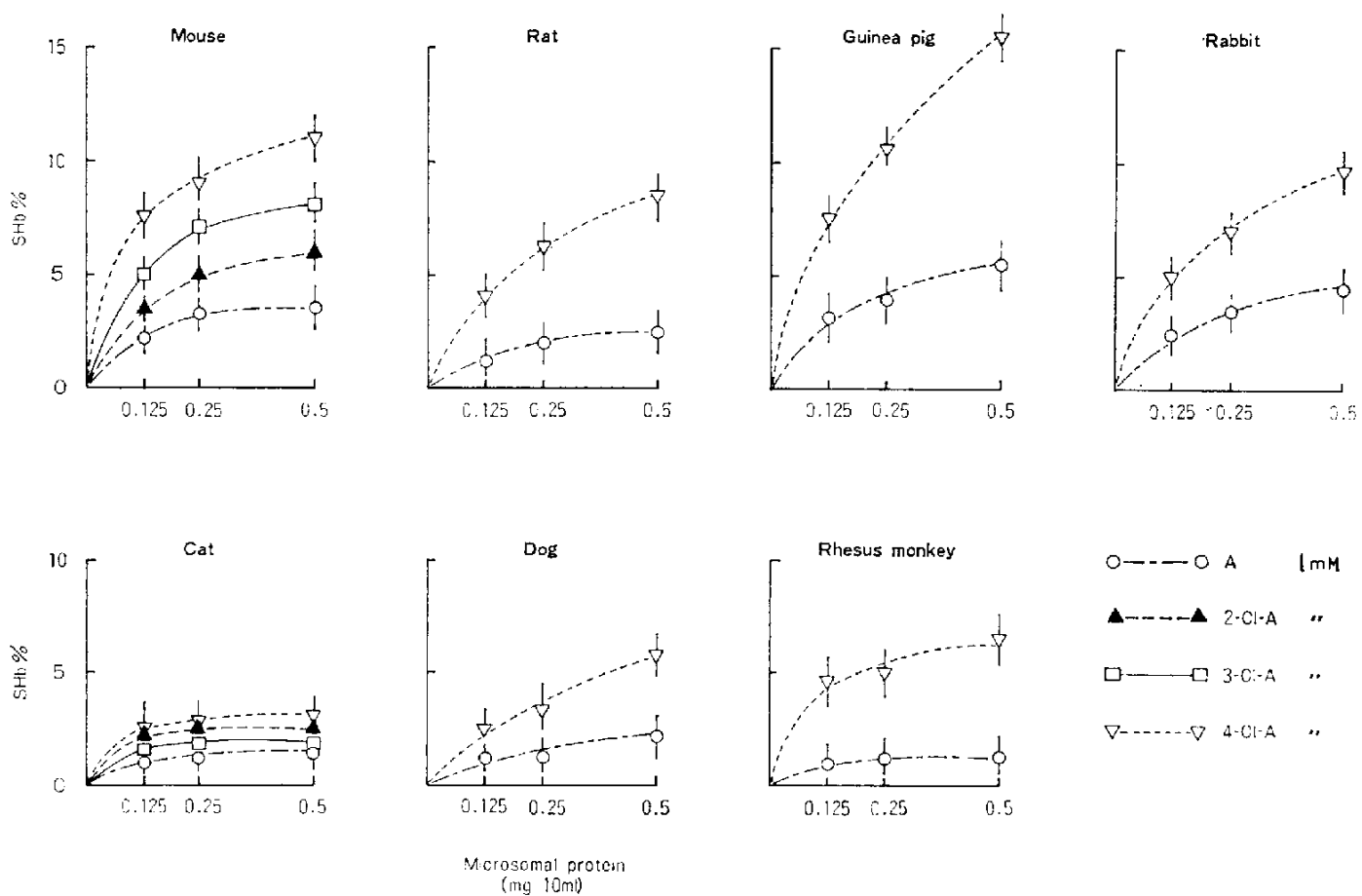

Fig. 6. Species differences of sulthemoglobin formation by $N$-hydroxy metabolites of aniline derivatıves in erythrocytes of guinea pigs. The substrates [aniline (A), 2chloroaniline (2-Cl-A). 3-chloroaniline (3-Cl-A) and 4-chloroaniline (4-Cl-A)] and the liver microsomes from animals of various species were incubated at $37^{\circ} \mathrm{C}$ for $60 \mathrm{~min}$. and the mixture was added to erythrocytes in the presence of sodium sulfide and the preparation was incubated for a further $30 \mathrm{~min}$. The final concentrations of hemoglobin and sodium sulfide in the erythrocyte suspension were adjusted to $10 \mathrm{~g} / \mathrm{dl}$ and $0.2 \mathrm{mM}$. respectively. Each value indicates the mean \pm standard error of 3 experiments.

added. It was thus confirmed that SHb was not produced via $\mathrm{MHb}$.

The incubation of aniline with erythrocytes resulted in little formation of either $\mathrm{MHb}$ or $\mathrm{SHb}$, but formation of both $\mathrm{MHb}$ and $\mathrm{SHb}$ was apparent when liver microsomes were added to the incubated reaction mixture. Thus SHb was also formed by $\mathrm{N}$-hydroxy metabolites.

Even though there was little $\mathrm{MHb}$ and $\mathrm{SHb}$ formation without microsomes following the treatment with aniline, these formation might be caused by the possible existence of a certain conversion mechanism in erythrocytes, because nitrobenzene was detected in the reaction mixture containing erythrocytes and aniline (21).

The reason why $\mathrm{SHb}$ formation in intact cells was more efficient than that in hemolysates may be that PHA and sulfide were taken up effectively by the cells, and that hemoglobin was extremely concentrated more in the cells than that in hemolysate solution.

\section{2) Correlation between the chemical} structure and $\mathrm{MHb}$ and $\mathrm{SHb}$ formation: In previous work we referred to the correlation between the chemical structure (aniline and anthranilic acid derivatives) and the formation of $\mathrm{MHb}$ and $\mathrm{SHb}$ in vivo (1-3). In this study, the rates of $\mathrm{MHb}$ and $\mathrm{SHb}$ formation used as indices of production rates of $\mathrm{N}$-hydroxy 

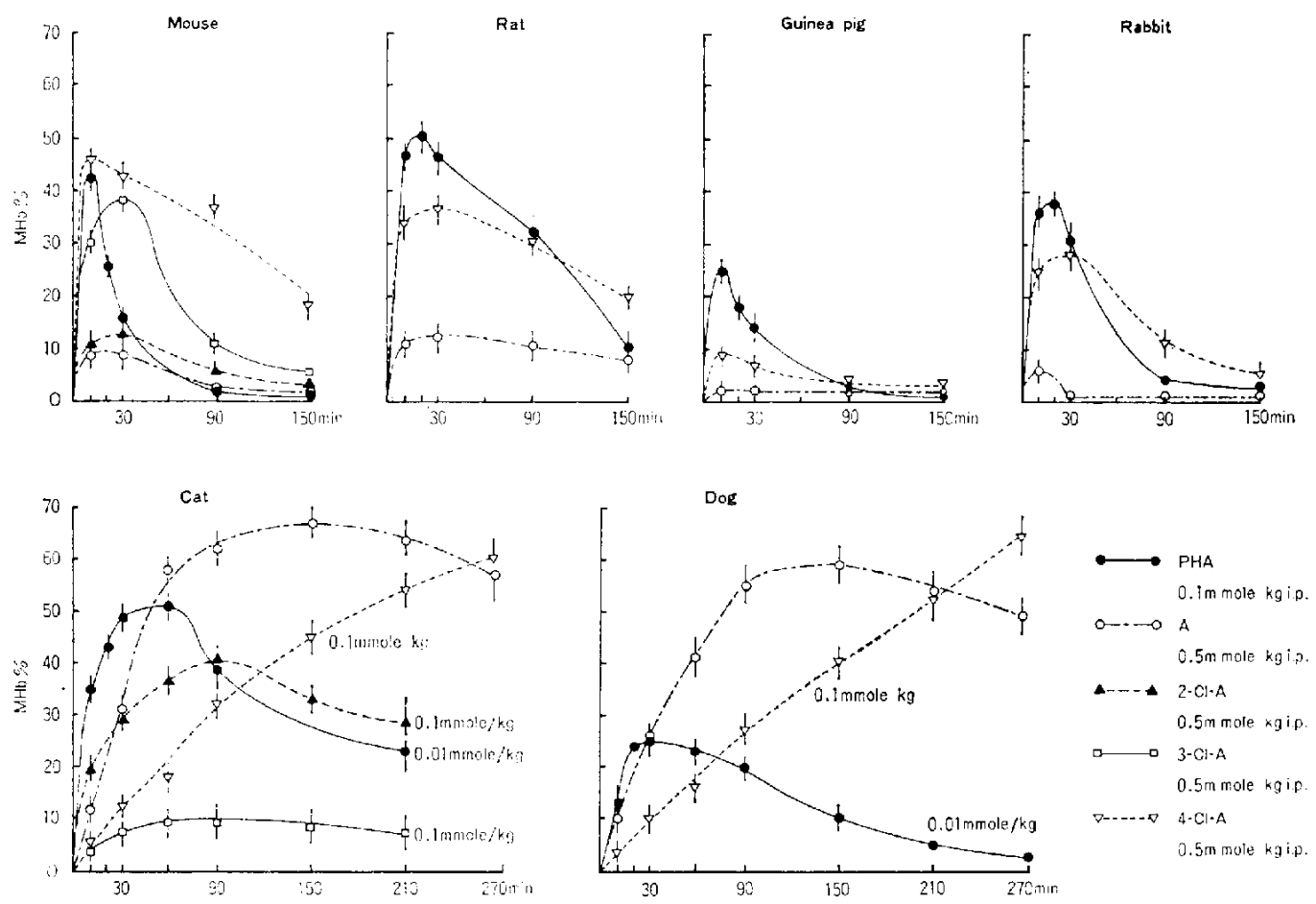

Fig. 7. Species differences of methemoglobin formation, in vivo after a single administration of phenylhydroxylamine (PHA), aniline (A), 2-chloroaniline (2-Cl-A), 3-chloroaniline (3- $\mathrm{Cl}-\mathrm{A})$ and 4-chloroaniline (4-Cl-A) to animals of various species. Each value indicates the mean \pm standard error of $10,5,5,3,3$, and 3 experiments of mice, rats, guinea pigs, rabbits, cats and dogs, respectively.

metabolites from aniline derivatives by liver microsomes in vitro were compared with the formation rates of $\mathrm{MHb}$ and $\mathrm{SHb}$ in vivo. We found that the order of amounts of $\mathrm{N}$ hydroxy metabolites was in parallel with the rates of $\mathrm{MHb}$ formation in vivo. This relationship was also observed in the cases of the $\mathrm{SHb}$ formation as described previously (1). Therefore, it would be possible to estimate the correlation between the chemical structure and $\mathrm{MHb}$ and $\mathrm{SHb}$ formation from the production rate of $\mathrm{N}$-hydroxy metabolites in vitro.

3) Species differrences in $\mathrm{MHb}$ and $\mathrm{SHb}$ formation: Species differences in $\mathrm{MHb}$ formation have been investigated in vivo (whole animals) $(12,22)$ as well as in vitro (using liver microsomes) $(15,23-28)$. When aniline (as well as 4-Cl-A) was incubated with liver microsomes from various species, there was a production of $\mathrm{N}$-hydroxy metabolites, as assessed by $\mathrm{MHb}$ and $\mathrm{SHb}$ formation. In cats, dogs and monkeys, the production rate was low, but it was extremely high in guinea pigs. The high $\mathrm{N}$-hydroxylation activity of guinea pigs was also reported by Uehleke (15). Appel et al. (25) and Debackere and Uehleke (23).

We found that the formation of $\mathrm{MHb}$ and $\mathrm{SHb}$ in vivo was extremely high in cats and dogs, as compared with that in guinea pigs. These results were contrary to the production rates in vitro. The high level of $\mathrm{MHb}$ in both species may be due to: a) deficiency of the glucuronyl transferase system in cats causing a higher level in the blood of the induced 


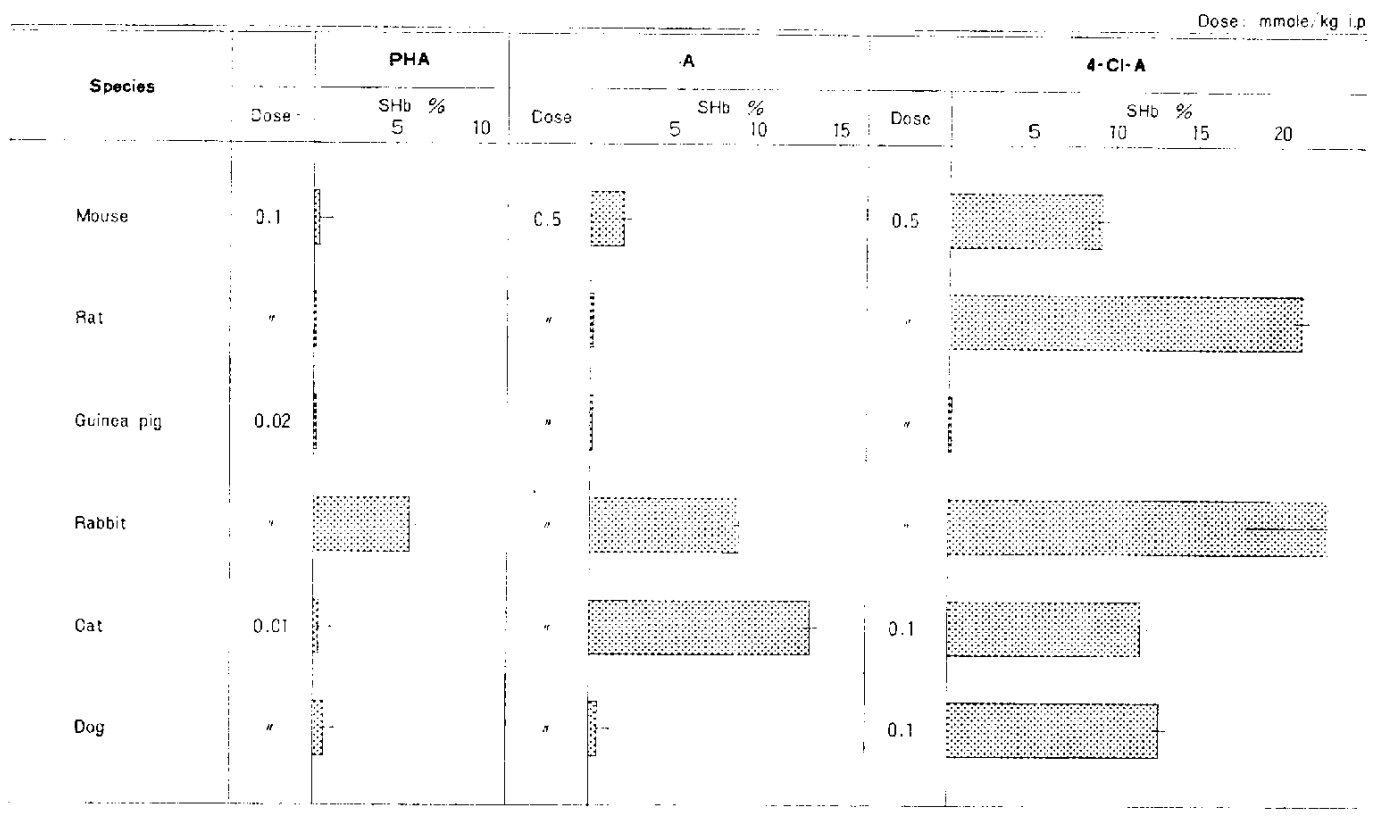

Fig. 8. Species differences of sulfhemoglobin formation, in vivo after the consecutive admınistration of phenylhydroxylamine (PHA), aniline (A) and 4-chloroaniline (4-Cl-A) to animals of various species for three days. The levels of sulfhemoglobin were measured $48 \mathrm{hr}$ after the final administration of drugs. Each value indicates the mean \pm standard error of $10,5,5,3,3$, and 3 experiments of mice, rats, guinea pigs, rabbits, cats and dogs, respectively.

arylhydroxylamines for a comparatively long time (11), b) arylamines remained unchanged in a higher level in dogs because as such have a lower acetylation capability (11). In addition, it might be considered that $\mathrm{MHb}$ formation was less induced by the effect of high $\mathrm{MHb}$ reductase activity which was found in rabbits, rats and mice (11). However, the discrepancy between in vivo and in vitro results in guinea pigs cannot be fully explained at present. The discrepancy in the case of $\mathrm{SHb}$ formation can hardly be explained from the view of enzymatic activity such as $\mathrm{MHb}$ reductase, because of the irreversible property of $\mathrm{SHb}(29,30)$.

As the levels of $\mathrm{MHb}$ induced by $\mathrm{PHA}$ in the erythrocyte suspension were slightly higher in dogs and cats than that in guinea pigs, it is assumed that this phenomenon reflected species differences for $\mathrm{MHb}$ for- mation in vivo. In the case of SHb formation, the results in vitro did not follow the species differences in vivo; $\mathrm{SHb}$ formation in the erythrocyte suspension was less prominent in dogs and cats than in the other species. The following are significant for a proper understanding the unexpected results in species differences: a) There were differences in some properties of hemoglobin of individual animal species, b) There were differences in the reduction mechanism of $\mathrm{MHb}$ within erythrocytes through the pentose phosphate shunt, c) The formation of $\mathrm{N}$ hydroxy metabolites in the body was induced not only in the liver but in other organs such as lung and kidney $(11,15,31,32)$, d) $\mathrm{N}$ Hydroxy compounds were further metabolized through the glucuronic acid conjugation, the $\mathrm{N}$-acetylation, the reduction of $\mathrm{N}$-hydroxy moiety and so on in different manners in 
different animal species.

Acknowledgements: We thank Mr. Y. Sasaki and Mrs. F. I waku for technical assistance. A part of this work was presented at the 53rd Regional Meeting of the Japanese Pharmacological Society (Wakayama, June 16. 1978).

\section{REFERENCES}

1) Nomura, A.: Studies on sulfhemoglobin formation by various drugs (1). Folia Pharmacol. japon. 71, 351-365 (1975) (Abs. in English)

2) Nomura, A.: Studies on sulfhemoglobin formation by various drugs (2). Folia Pharmacol. japon. 73, 423-435 (1977) (Abs. in English)

3) Nomura, A.: Studies on sulfhemoglobin formation by various drugs (3). Folia Pharmacol. japon. 73, 793-802 (1977) (Abs. in English)

4) Nomura, A.: Studies on sulfhemoglobin formation by various drugs (4). Influences of various antidotes on chemically induced methemoglobinemia and sulfhemoglobinemia. Folia Pharmacol. japon. 76, 435-446 (1980) (Abs. in English)

5) Evelyn, K.A. and Malloy, H.T.: Microdetermination of oxyhemoglobin. methemoglobin and sulfhemoglobin in a sigle sample of blood. $J$. biol. Chem. 126, 655-662 (1938)

6) Hogeboom, G.H.: Fractionation of cell components of animal tissues. Method in Enzymology. Edited by Colowick. S.P. and Kaplan. N.O., Vol. 1, p. 16-18. Academic Press. New York (1955)

7) Gornall, A.G., Bardawill, C.J. and David, M.M.: Determination of serum proteins by means of the biuret reaction. J. biol. Chem. 177, 751-766 (1949)

8) Hjelm, M. and de Verdier, C.-H.: Biochemical effects of aromatic amines-l. Methemoglobinemia, hemolysis and Heinz-body formation induced by 4.4-diaminodiphenylsulphone. Biochem. Pharmacol. 14, 1119-1128 (1965)

9) Kiese, M.: Oxidation von Anilin zu Nitrosobenzol im Hunde. Naunyn-Schmiedebergs Arch. exp. Path. Pharmakol. 235, 354-359 (1959)

10) Kiese, M.: The effect of certain substituents upon the $\mathrm{N}$-oxidation of aniline in vivo. Naunyn-Schmiedebergs Arch. exp. Path. Pharmakol. 244, 387-404 (1963)

11) Weisburger, J.H. and Weisburger, E.K.: Biochemical formation and pharmacological, toxicological, and pathological properties of hydroxylamines and hydroxamic acids. Phar- macol. Rev. 25, 1-66 (1973)

12) Kiese, M.: The biolchemical production of ferrihemoglobin-forming derivatives from aromatic amines, and mechanisms of ferrihemoglobin formation. Pharmacol. Rev. 18, 10911161 (1966)

13) Kramer, P.A., Glader, B.E. and Li, T.-K.: Mechanism of methemoglobin formation by diphenylsulfones. Effect of 4-amino-4'hydroxyaminodiphenylsulfone and other $p$ substituted derivatives. Biochem. Pharmacol. 21, 1265-1274 (1972)

14) Uehleke, H.: Stoffwechsel von Arzneimittein als Ursache von Wirkungen. Nebenwirkungen und Toxizität. Fortschr. Arzneim. Forsch. 15, 147203 (1971)

15) Uehleke, H.: Toxikologische Aspecte der $\mathrm{N}$ Hydroxylierung aromatischer Amine. NaunynSchmiedebergs Arch. Pharmakol. exp. Pathol. 263, 106-120 (1969)

16) Miller, J.A.: Carcinogenesis by chemicals: An overview-C.H.A. Clowes Memorial Lecture. Cancer Res. 30, 559-576 (1970)

17) Radomski, J.L. and Brill, E.: Bladder cancer induction by aromatic amine: Role of $\mathrm{N}$-hydroxy metabolites. Science 167, 992-993 (1970)

18) Nichol, A.W., Hendry, I. and Morell, D.B.: Mechanism of formation of sulfhemoglobin. Biochim. Biophys. Acta 156, 97-108 (1968)

19) Nicholls, P.: The formation and properties of sulfhemogiobin and sulphcatalase. Biochem. $J$. 81, 374-383 (1961)

20) Allen, D.W. and Jandl, J.H.: Oxidative hemolysis and precipitation of hemoglobin. II Role of thiol in oxidant drug action. J. clin. Invest. 40, 454-475 (1961)

21) Kiese, $M$. and Uehleke, $H .:$ Der Ort der $N$ Oxydation des Anilins in höheren Tier, NaunynSchmiedebergs Arch. exp. Path. Pharmakol. 242, 111-129 (1961)

22) Spicer, S.S.: Species differences in susceptibility to methemoglobin formation. J. Pharmacol. exp. Ther. 99, 185-194 (1950)

23) Debackere, M. and Uehleke, $H_{\text {.: }} \mathrm{C}$ - and $\mathrm{N}$ Hydroxylation of aromatic amines by isolated liver microsomes of different species. Proc. Eur. Soc. Study Drug Toxicity 4, 40-44 (1964)

24) Lotlikar, P.D., Enomoto, M., Miller, J.A. and Miller, E.C.: Species variations in the $\mathrm{N}$ - and ring-hydroxylation of 2-acetylaminofluorene and effects of 3-methylcholanthrene pretreatment. Proc. Soc. exp. Biol. Med. 125, 341-346 (1967)

25) Appel, W., Graffe, W., Kampffmeyer, H. and Kiese, M.: Species differences in the hydroxylation of aniline and $\mathrm{N}$-ethylaniline by liver 
microsomes. Naunyn-Schmiedebergs Arch. exp. Path. Pharmak. 251, 88-94 (1965)

26) Chow, A.Y.K. and Murphy, S.D.: Propanil (3.4dichloropropionanilide)-induced methemoglobin formation in relation to its metabolism in vitro. Toxicol. appl. Pharmacol. 33, 14-20 (1975)

27) Smith, M.R. and Gorrod, J.W.: The microsomal $\mathrm{N}$-oxidation of some primary aromatic amines. Biological Oxidation of Nitrogen. Edited by Gorrod. J.W., p. 65-70. Elsevier/North-Holland Biomedical Press, Amsterdam. New York. Oxford (1978)

28) Smith, M.R., Damani, L.A., Disley, L.G., Gorrod, J.W., Marsden, J.T., Paterson, L.H. and Rhenius, S.T.: Ferrihemoglobin formation by $\mathrm{N}$-oxidation products of certain compounds in the rabbit. Biological Oxidation of Nitrogen, Edited by Gorrod, J.W., p. 363-368, Elsevier/North-
Holland Biomedical Press, Amsterdam. New York, Oxford (1978)

29) Kneezel, L.D. and Kitchens, C.S.: Phenacetininduced sulfhemoglobinemia: Report of case and review of the literature. Johns Hopkins Med. J. 139, 175-177 (1976)

30) Faukner, W.R., King, J.W. and Damm, H.C.: Handbook of Clinical Laboratory Data, 2nd Edition, p. 341-342, The Chemical Rubber Co.. Ohio (1968)

31) Uehleke, H.: N-Hydroxylierung von $p-$ Phenetidin in vivo und durch isolierte Mikrosomen aus Lebern und Nieren: Stimulierung druch Phenobarbital-Vorbehandlung. NaunynSchmiedebergs Arch. Pharmakol. exp. Pathol. 264, 434-461 (1969)

32) Uehleke, H.: N-Hydroxylation. Xenobiotica 1 , $327-338(1971)$ 